\title{
PERNERAPAN MODEL PERSAMAAN SIMULTAN DENGAN PENDEKATAN TWO STAGE LEAST SQUARE PADA KASUS INFLASI DAN NILAI TUKAR RUPIAH DI INDONESIA
}

\author{
Rahmawati Yusuf ${ }^{1 *}$, Resmawan ${ }^{2}$, Boby Rantow Payu ${ }^{3}$ \\ 1,2 Jurusan Matematika, Universitas Negeri Gorontalo, Bone Bolango 96119, Indonesia \\ ${ }^{3}$ Jurusan Ekonomi, Universitas Negeri Gorontalo, Kota Gorontalo 96128, Indonesia \\ *Penulis Korespondensi: amarahma031@gmail.com
}

\begin{abstract}
Abstrak
Dalam penggunaan model regresi terdapat variabel yang saling berhubungan satu sama lain, sehingga dibutuhkan metode yang dapat mengakomodir variabel tersebut, yakni metode persamaan simultan. Penelitian ini bertujuan untuk menentukan faktor yang mempengaruhi inflasi dan nilai tukar rupiah serta memodelkan persamaan simultan terhadap faktor yang mempengaruhi inflasi dan nilai tukar rupiah di Indonesia dengan pendekatan two stage least square. Data dalam penelitian ini menggunakan data sekunder yang diperoleh dari website Badan Pusat Statistik. Hasil penelitian menunjukan bahwa model persamaan simultan dengan pendekatan two stage least square variabel yang signifikan berpengaruh terhadap inflasi adalah nilai tukar rupiah dan jumlah uang beredar. Sementara itu, variabel yang signifikan berpengaruh terhadap nilai tukar rupiah adalah inflasi dan jumlah uang beredar. Berdasarkan nilai prediksi dengan menggunakan persamaan inflasi dan nilai tukar rupiah menghasilkan nilai MAPE yang diperoleh tidak melebihi $50 \%$, sehingga dapat disimpulkan bahwa hasil prediksi dengan menggunakan persamaan inflasi dan nilai tukar rupiah menunjukan hasil prediksi yang akurat.
\end{abstract}

Kata Kunci: Persamaan Simultan; Two Stage Least Square; Inflasi; Nilai Tukar Rupiah

\begin{abstract}
Using the regression model, a method that accommodates variables related to each other is called the simultaneous equation method. The study aims to determine the factors affecting inflation and rupiah exchange rate and model simultaneous equations towards the factors affecting inflation and rupiah exchange rate in Indonesia using Two-Stage Least Square. Data used in this study are secondary data obtained from the website of Statistics of Indonesia. Findings on the simultaneous equation model with two-stage least squares reveal that variables that significantly affect inflation are the Indonesia rupiah exchange rate and money supply. At the same time, variables that significantly affect the Indonesian rupiah exchange rate are inflation and money supply. The predictive value using the inflation and rupiah exchange rate equation indicates that the obtained MAPE (Mean Absolute Percentage Error) value does not exceed $50 \%$. In conclusion, the prediction result using the inflation and Indonesia rupiah exchange rate equation is accurate.
\end{abstract}

Keywords: Simultaneous Equations; Two-Stage Least Square; Inflation; Indonesian Rupiah Exchange Rate

\section{Pendahuluan}

Suatu model statistik yang digunakan dalam penentuan hubungan sebab akibat diantara satu variabel dengan variabel yang lain disebut analisis regresi. Model regresi yang paling banyak di jumpai dalam statistika biasanya berupa model persamaan tunggal (single equation model). Namun, tidak menutup kemungkinan terdapat interdependensi yaitu keterkaitan diantara variabel sehingga terbentuk hubungan dua arah pada beberapa model. Dalam bidang ekonometrika model yang seperti ini dikenal dengan suatu model persamaan simultan [1]. 
Model persamaan simultan merupakan sebuah model yang menjelaskan variabel endogen secara bersama-sama [2]. Sementara itu, model persamaan simultan memiliki satu variabel yang mempunyai dua peranan sekaligus [3]. Berbeda dengan persamaan tunggal, dalam model persamaan simultan estimasi parameternya tidak dapat dilakukan tanpa mempertimbangkan informasi pada persamaan lainnya [4].

Pada persamaan simultan, suatu variabel endogen akan menjadi variabel eksogen pada persamaan lain sehingga kemungkinan berkorelasi dengan error cukup besar (tejadi endogenitas). Oleh karena itu dibutuhkan metode untuk mengatasi masalah endogenitas. Beberapa metode yang dapat digunakan diantaranya The Reduced-Form Equations, Two-Stage Least Square, Indirect Least Square, dan Three-Stage Least Squares. Dalam pemodelan ekonomi penggunaan metode Two-Stage Least Square ialah metode yang tepat, karena metode estimasi ini dapat digunakan pada kondisi identified maupun over identified [5].

Dalam menyusun sebuah model ekonomi, diperlukan ketelitian yang kuat dalam memilih variabel-variabel yang saling berhubungan. Sesuai dengan karakteristik dari setiap variabel ekonomi yang bersifat sebagai variabel independen, akan tetapi di satu sisi variabel tersebut dapat menjadi variabel dependen [6]. Misalnya hubungan antara inflasi dan nilai tukar. Salah satu variabel ekonomi makro yang sangat penting ialah nilai tukar atau yang dikenal dengan KURS, hal ini dikarenakan pergerakan nilai kurs dapat mempengaruhi stabilitas ekonomi termasuk di dalamnya inflasi. Akan tetapi di satu pihak inflasi juga dipengaruhi oleh tingkat suku bunga maupun jumlah uang beredar [7]. Peningkatan inflasi mengakibatkan barang-barang pokok ikut melambung, tingkat harga barang-barang tersebut juga dipengaruhi oleh nilai tukar Rupiah [8]. Inflasi akan membawa pengaruh terhadap peningkatan harga barang-barang di negara tersebut apabila terjadi perubahan tingkat harga pada suatu negara [9]. Selain inflasi, nilai tukar juga mempengaruhi perekonomian suatu negara [10]. Peningkatan nilai tukar rupiah terhadap nilai mata uang asing dapat mengakibatkan naiknya inflasi. Untuk memperoleh taksiran yang tepat maupun estimasi terbaik, maka kita harus mengakomodir setiap variabel yang ada dalam bidang ekonomi tersebut. Dalam penggunaan model regresi terdapat metode yang dapat mengakomodir variabel yang saling berhubungan satu sama lain. Metode tersebut adalah 2SLS atau dikenal dengan model persamaan simultan. Metode 2SLS diperkenalkan oleh Theil [11] dan Basmann [12].

Beberapa penelitian mengenai pertumbuhan ekonomi antara lain Kuznets [13] melakukan prediksi terhadap pertumbuhan ekonomi dan Produk Domestik Regional Bruto (PDRB) dengan menerapkan model persamaan simultan dengan pendekatan metode 2SLS. Dimana Produk Domestik Bruto (PDB) dipengaruhi oleh pertumbuhan ekonomi, ekspor dan impor. Selanjutnya pertumbuhan ekonomi di pengaruhi oleh Produk Domestik Bruto (PDB), Tingkat Pengangguran, dan kepadatan penduduk. Kemudian Misno [14] melakukan penelitian dalam mengestimasi model persamaan simultan dengan metode 2SLS pada pemodelan kemiskinan dan pengangguran. Hasilnya diperoleh bahwa penganguran dan IPM berpengaruh terhadap Kemiskinan, dan pengangguran di pengaruhi oleh kemiskinan dan jumlah penduduk dan Rahmadeni [15] melakukan penelitian mengenai pemodelan persamaan simultan terhadap analisis hubungan inflasi dan nilai tukar Hasil penelitiannya menunjukkan bahwa tingkat suku bunga berpengaruh signifikan terhadap inflasi dan variabel nilai tukar di pengaruhi oleh Produk Domestik Bruto (PDB).

Beberapa penelitian yang sudah dilakukan sebelumnya menunjukkan bahwa dalam bidang ekonomi dapat menggunakan sistem persamaan simultan dikarenakan variabel-variabelnya cenderung memiliki hubungan yang simultan. Berdasarkan fenomena, adanya keterkaitan antara variabel-variabel ekonomi sehingga tidak dapat dilakukan pemodelan dengan model regresi sederhana ataupun berganda, maka dalam penelitian ini digunakan metode 2SLS terhadap faktor yang mempengaruhi nilai tukar rupiah dan inflasi.

\section{Metode Penelitian}

Penelitian ini dilakukan selama 5 bulan dimulai sejak bulan Februari hingga Juni tahun 2021. Adapun variabel yang digunakan yakni variabel Inflasi, Nilai Tukar Rupiah, Produk Domestik Bruto (PDB), Jumlah Uang Beredar, dan Tingkat Suku Bunga. Data pada penelitian ini merupakan 
data sekunder yang diperoleh dari website Badan Pusat Statistik (BPS) Indonesia pada tahun 19992020. Teknik pengambilan sampel yang digunakan adalah sampling jenuh. Metode analisis yang digunakan yaitu Persamaan Simultan dengan Pendekatan Two Stage Least Square.

Dalam menganalisis data menggunakan software eviews 10. Adapun langkah-langkah analisis dalam penelitian ini adalah sebagai berikut:

a. Mendeskripsikan karakteristik inflasi dan nilai tukar rupiah dan inflasi

b. Membuat model persamaan simultan

c. Identifikasi masalah

d. Estimasi parameter dengan menggunakan pendekatan Two Stage Least Square

e. Pengujian asumsi klasik

f. Memprediksi nilai dengan menggunakan model persamaan inflasi dan nilai tukar rupiah

g. Kesimpulan

\section{Hasil dan Pembahasan}

\subsection{Analisis Deskriptif}

\subsubsection{Karateristik Variabel Inflasi (INF)}

Dalam mendeskripsikan Karakteristik variabel inflasi (INF) dan faktor-faktor yang mempengaruhinya dapat dijelaskan dalam Tabel 1.

Tabel 1. Karateristik Variabel Inflasi (INF)

\begin{tabular}{crrrr}
\hline Variabel & \multicolumn{1}{c}{ Mean } & \multicolumn{1}{c}{ Minimum } & Maksimum & Standar Deviasi \\
\hline INF & 6,31 & 1,68 & 17,11 & 3,93 \\
ER & $10.819,68$ & $7.100,00$ & $14.481,00$ & $2.227,66$ \\
$M_{2}$ & $2.896,01$ & $6.462,05$ & $6.900,049$ & $2.004,90$ \\
R & 8,39 & 4,25 & 17,62 & 3,55 \\
\hline
\end{tabular}

Berdasarkan Tabel 1 dapat diketahui bahwa rata-rata inflasi (INF) sebesar 6,31\%, nilai minimum sebesar $1,68 \%$, nilai maksimum sebesar $17,11 \%$ dan standar deviasi sebesar $3,93 \%$. Nilai tukar rupiah (ER) memiliki rata-rata sebesar Rp 10.819,68, nilai minimum sebesar Rp 7.100,00, nilai maksimum sebesar Rp 14.481,00, dan standar deviasi sebesar Rp 2.227,66. Jumlah uang beredar (M2) memiliki rata-rata sebesar Rp 2.896,01 Miliar, nilai minimum sebesar Rp 6.462,05 Miliar, nilai maksimum sebesar Rp 6.900,05 Miliar dan standar deviasi sebesar Rp 2.004,90 Miliar. Tingkat suku $(\mathrm{R})$ bunga memiliki rata-rata sebesar 8,39\%, nilai minimum sebesar 4,25\%, nilai maksimum sebesar $17,62 \%$ dan standar deviasi sebesar 3,55\%.

\subsubsection{Karakteristik Variabel Nilai Tukar Rupiah(ER)}

Dalam mendeskripsikan Karakteristik variabel nilai tukur rupiah (ER) dan faktor-faktor yang mempengaruhinya dapat dijelaskan dalam Tabel 2.

Tabel 2. Karateristik Variabel Nilai Tukar Rupiah (ER)

\begin{tabular}{crrrr}
\hline Variabel & \multicolumn{1}{c}{ Mean } & \multicolumn{1}{c}{ Minimum } & \multicolumn{1}{c}{ Maksimum } & \multicolumn{1}{c}{ Standar Deviasi } \\
\hline ER & $10.819,68$ & $7.100,00$ & $14.481,00$ & $2.227,66$ \\
INF & 6,31 & 1,68 & 17,11 & 3,93 \\
$M_{2}$ & $2.896,01$ & $6.462,05$ & $6.900,05$ & $2.004,90$ \\
PDB & 4,82 & 0,80 & 6,50 & 1,40 \\
\hline
\end{tabular}

Berdasarkan Tabel 2 dapat diketahui bahwa rata-rata nilai tukar rupiah (ER) sebesar Rp 10.819,68, nilai minimum sebesar Rp 7.100,00, nilai maksimum sebesar Rp 14.481,00 dan standar deviasi sebesar Rp 2.227,66. Inflasi (INF) memiliki rata-rata sebesar 6,31\%, nilai minimum sebesar $1,68 \%$, nilai maksimum sebesar $17,11 \%$ dan standar deviasi sebesar 3,93\%. Jumlah uang beredar 
(M2) memiliki rata-rata sebesar Rp 2.896,01 Miliar, nilai minimum sebesar Rp 6.462,05 Miliar, nilai maksimum sebesar Rp 6.900,05 Miliar dan standar deviasi sebesar Rp 2.004,90 Miliar. PDB memiliki rata-rata sebesar $4,82 \%$, nilai minimum sebesar $0,80 \%$, nilai maksimum sebesar $6,50 \%$ dan standar deviasi sebesar $1,40 \%$.

\subsection{Gambaran Umum Variabel}

\subsubsection{Gambaran Umum Variabel Inflasi (INF)}

Untuk mengetahui perkembangan inflasi di Indonesia dalam periode 1999-2020 dijelaskan pada Gambar 1.

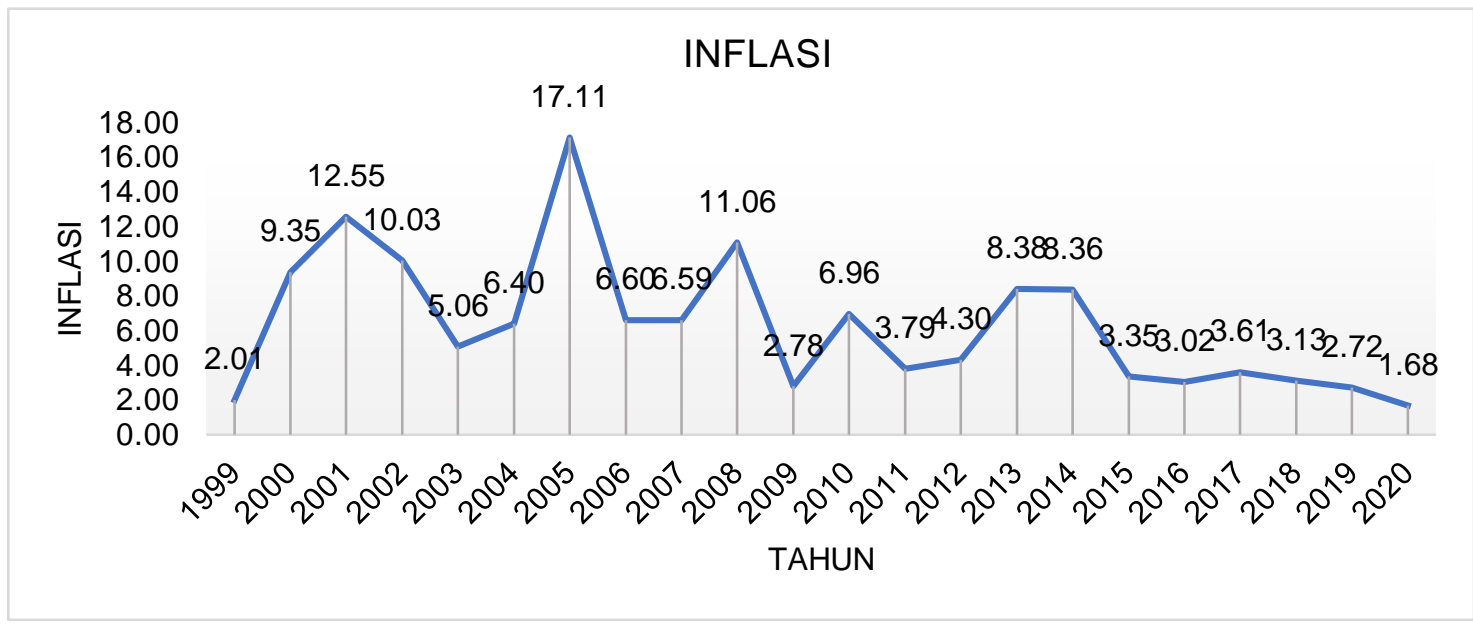

Gambar 1. Gambaran Umum Variabel Inflasi

Berdasarkan Gambar 1 dapat diketahui bahwa perkembangan inflasi pada tahun 1999-2020 mengalami perubahan dari waktu ke waktu. Indonesia mengalami tingkat inflasi tertinggi pada tahun 2005 sebesar 17,11\% dan tingkat inflasi terendah pada tahun 2020 sebesar 1,68\%.

\subsubsection{Gambaran Umum Variabel Nilai Tukar Rupiah (ER)}

Untuk mengetahui perkembangan nilai tukar rupiah di Indonesia dalam periode 1999-2020 dijelaskan pada Gambar 2.

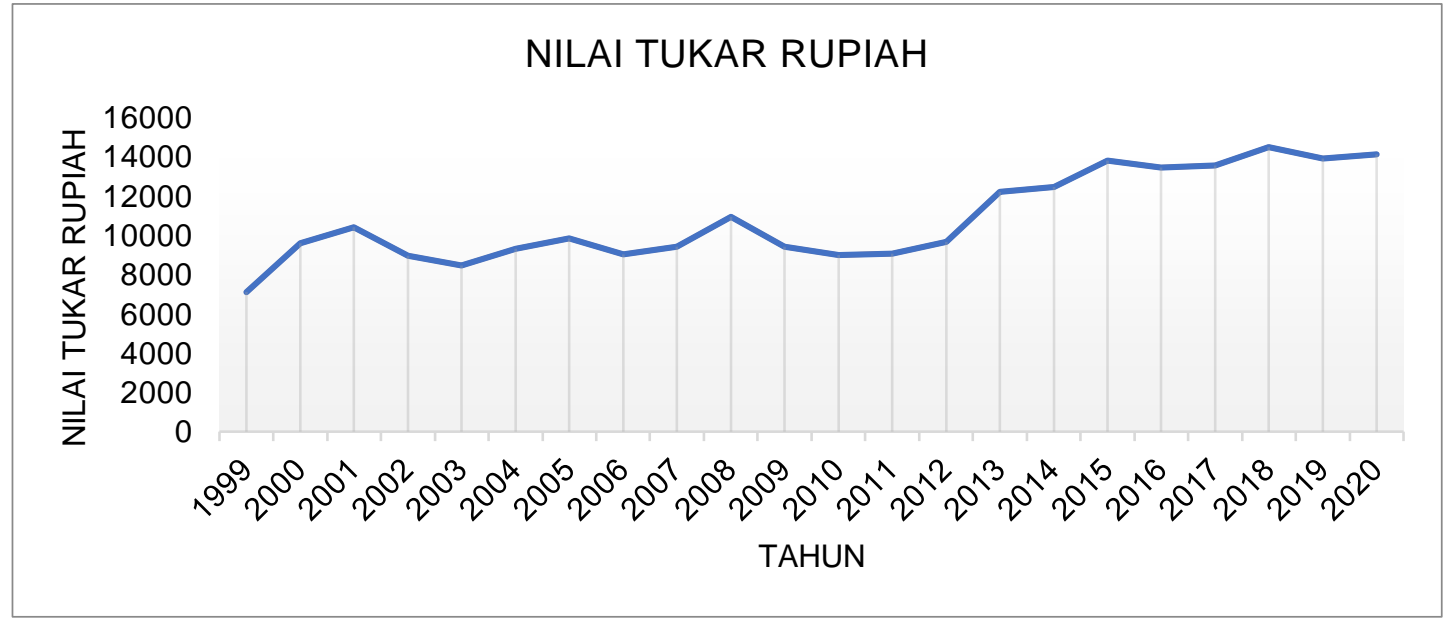

Gambar 2. Gambaran Umum Variabel Nilai Tukar Rupiah

Berdasarkan Gambar 2 dapat diketahui bahwa perkembangan nilai tukar rupiah tahun 19992020 mengalami perubahan dari waktu ke waktu. Perubahan nilai tukar rupiah dapat dikatakan tidak 
stabil, dengan tingkat terendah pada tahun 1999 sebesar Rp.7100, sedangkan pada tahun 2020 nilai tukar rupiah di indonesia mengalami peningkatan sebesar Rp.14105.

\subsubsection{Gambaran Umum Variabel Jumlah Uang Beredar $\left(M_{2}\right)$}

Untuk mengetahui perkembangan jumlah uang beredar di Indonesia dalam periode 1999. 2020 dijelaskan pada Gambar 3.

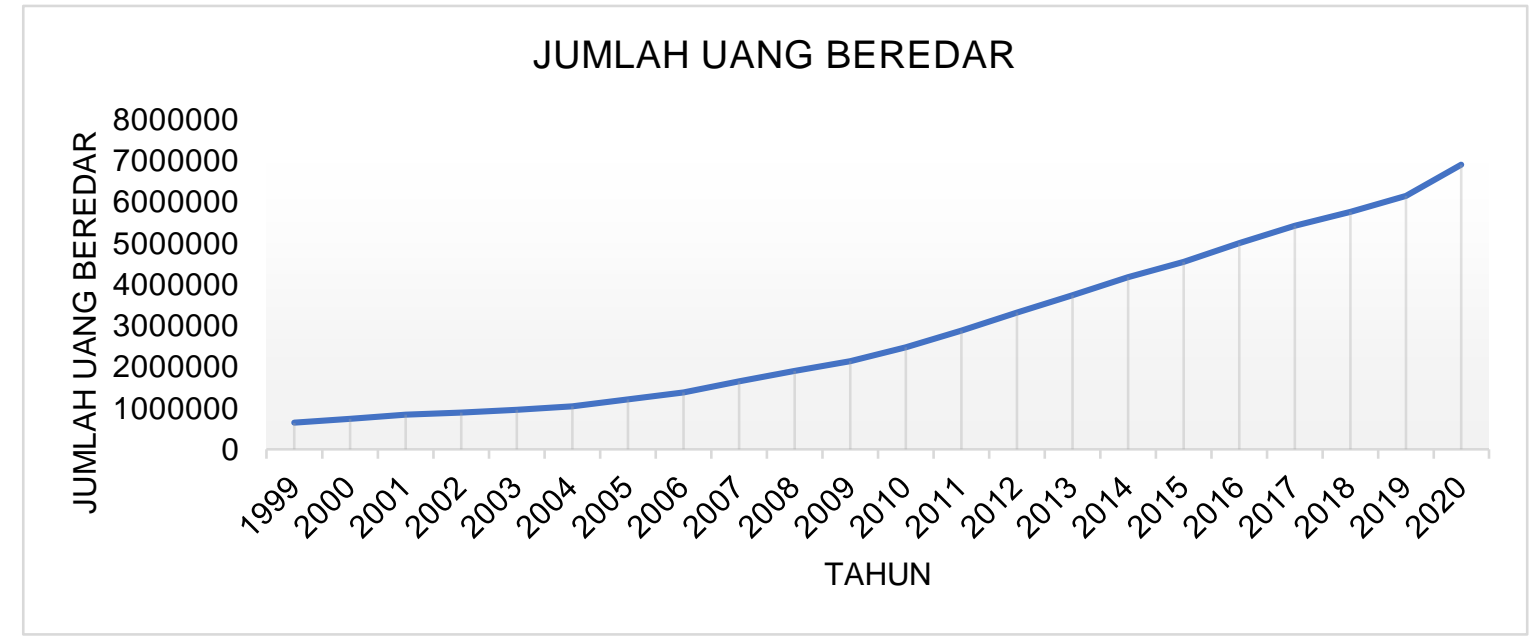

Gambar 3. Gambaran Umum Variabel Jumlah Uang Beredar

Berdasarkan Gambar 3 diketahui bahwa jumlah uang beredar $\left(M_{2}\right)$ pada tahun 1999- 2020 mengalami peningkatan hingga mencapai angka tertinggi sebesar 6.900.049 Miliar Rupiah.

\subsubsection{Gambaran Umum Variabel Tingkat Suku Bunga $(R)$}

Untuk mengetahui perkembangan nilai tukar rupiah di Indonesia dalam periode 1999-2020 dijelaskan pada Gambar 4.

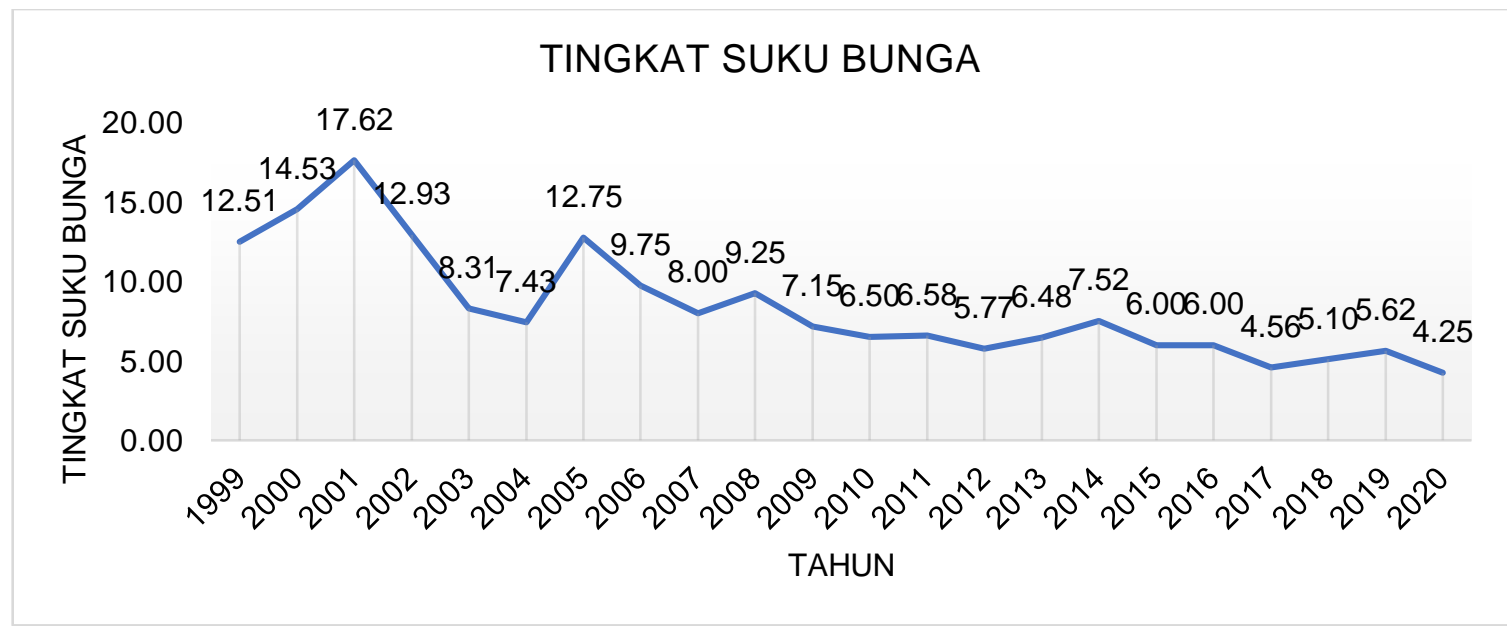

Gambar 4. Gambaran Umum Variabel Tingkat Suku Bunga

Berdasarkan Gambar 4 diketahui bahwa suku bunga di Indonesia pada tahun 1999-2020 mengalami perkembangan setiap tahunnya. Tingkat suku bunga tertinggi men- capai angka $17,62 \%$ pada tahun 2001 sampai pada tahun 2020 tingkat suku sebasar $4,25 \%$.

\subsubsection{Gambaran Umum Variabel Pertumbuhan Ekonimi (PDB)}

Untuk mengetahui perkembangan nilai produk domestik bruto di Indonesia dalam periode 


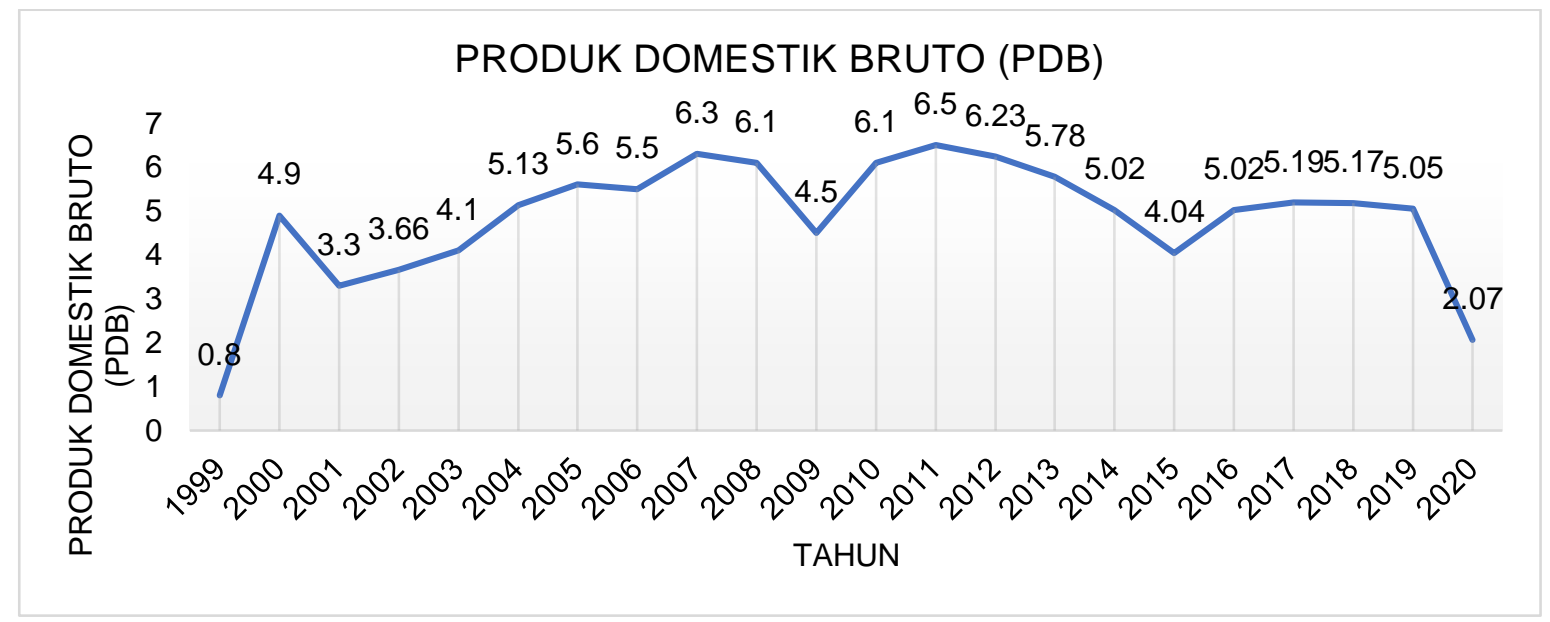

Gambar 5. Gambaran Umum Variabel Pertumbuhan Ekonomi

Berdasarkan Gambar 5 diketahui bahwa PDB di Indonesia mengalami fluktuasi dengan angka terendah adalah 0,8\% dan nilai PDB tertinggi adalah tahun 2011 yaitu sebesar 6,5\%.

\subsection{Model Persamaan Simultan}

Model inflasi dan nilai tukar rupiah yang dibuat mengacu pada penelelitian terdahulu, model tersebut sebagai berikut.

dimana

$$
\begin{aligned}
& Y_{1}=\alpha_{10}+\alpha_{11} Y_{2}+\beta_{11} X_{1}+\beta_{12} X_{2}+\varepsilon_{1} \\
& Y_{2}=\alpha_{20}+\alpha_{21} Y_{2}+\beta_{21} X_{2}+\beta_{23} X_{3}+\varepsilon_{2}
\end{aligned}
$$

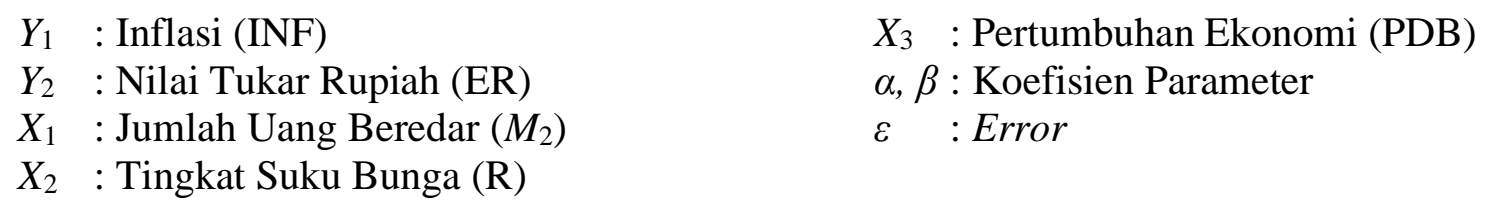

\subsection{Identifikasi Masalah}

Sebelum melakukan estimasi parameter perlu dilakukan identifikasi masalah terlebih dahulu, untuk melihat apakah model persamaan yang dibentuk bisa digunakan pendekatan Two Stage Least Square. Dalam mengidentifikasi masalah tersebut dapat menggunakan uji kondisi order dan kondisi rank.

\subsubsection{Uji Kondisi Order}

Berdasarkan kondisi order, model dikatakan teridentifikasi jika model persamaan (1) dan (2) memenuhi syarat apabila pada suatu model menunjukkan $\mathrm{K}-\mathrm{k} \geq \mathrm{m}-1$ maka disebut over identified. Apabila $\mathrm{K}-\mathrm{k}=\mathrm{m}-1$ maka disebut exactly identified dan apabila $\mathrm{K}-\mathrm{k}<\mathrm{m}-1$ maka persamaan tersebut dikatakan unidentified. Hasil pengujian dengan kondisi order dijelaskan dalam Tabel 3.

Tabel 3. Identifikasi Masalah Dengan Kondisi Order

\begin{tabular}{ccccc}
\hline Model Persamaan & $\mathrm{K}$ & $\mathrm{k}$ & $\mathrm{M}$ & $\mathrm{m}$ \\
\hline INF & 5 & 4 & 2 & 1 \\
ER & 5 & 4 & 2 & 1 \\
\hline
\end{tabular}


Keterangan:

$M$ : Jumlah seluruh variabel endogen pada model persamaan simultan

$m$ : Jumlah variabel endogen pada persamaan yang telah ditentukan

$K \quad$ : Jumlah seluruh variabel yang sudah ditetapkan dalam model, termasuk intersep

$k \quad$ : Jumlah variabel yang sudah ditetapkan pada persamaan yang diberikan

Berdasarkan hasil yang diperoleh pada Tabel 3 menunjukan bahwa model persamaan 1 dan 2 merupakan persamaan over identified yang artinya kedua model tersebut tepat teridentifikasi sehingga dapat digunakan pendekatan Two Stage Least Square.

\subsubsection{Uji Kondisi Rank}

Kondisi order hanya kondisi yang diperlukan, namun belum cukup menunjukan hasil identifikasi yang sebenarya, artinya walaupun dalam kondisi order persamaan teridentifikasi, ada kemungkinan persamaan tersebut tidak teridentifikasi apabila di- uji dengan kondisi rank. Dalam melakukan uji dengan kondisi rank dimana sebuah model persamaan dapat dikatakan teridentifikasi apabila memiliki satu determinan yang tidak sama dengan 0 . Determinan tersebut berdimensi ( $M-$ 1) yang dihasilkan dari koefisien-koefisien variabel yang tidak dimasukan dalam model persamaan yang lain. Hasil pengujian dengan kondisi rank sebagai berikut.

Untuk memudahkan identifikasi dengan menggunakan uji kondisi rank, model persamaan (1) dan (2) dapat dibentuk dalam Tabel 4.

Tabel 4. Parameter-Parameter dari Variabel

\begin{tabular}{ccccccc}
\hline \multirow{2}{*}{ Persamaan } & \multicolumn{6}{l}{ Koefisien dari variabel-variabel } \\
\cline { 2 - 7 } & Konstanta & $Y_{1}$ & $Y_{2}$ & $X_{1}$ & $X_{2}$ & $X_{3}$ \\
\hline$Y_{1}$ & $\alpha_{10}$ & 1 & $\alpha_{11}$ & $\beta_{11}$ & $\beta_{12}$ & 0 \\
$Y_{2}$ & $\alpha_{20}$ & $\alpha_{21}$ & 1 & $\beta_{21}$ & 0 & $\beta_{23}$ \\
\hline
\end{tabular}

Berdasarkan Tabel 4 persamaan inflasi $\left(Y_{1}\right)$ diketahui bahwa nilai koefisien dari variabel $X_{2}=0$, sehingga dapat dituliskan sebagai berikut.

$$
A=\left[\beta_{23}\right]
$$

Dapat disimpulkan bahwa Det $|\mathrm{A}| \neq 0$ artinya model persamaan inflasi (1) merupakan persamaan yang teridentifikasi sehingga pendekataan Two Stage Least Square dapat digunakan dan dilanjutkan dengan identifikasi untuk persamaan nilai tukar rupiah.

Berdasarkan Tabel 4 persamaan nilai tukar rupiah $\left(Y_{2}\right)$ diketahui bahwa nilai koefisien dari variabel $X_{2}=0$, sehingga dapat dituliskan sebagai berikut.

$$
B=\left[\beta_{12}\right]
$$

Dapat disimpulkan bahwa Det $|\mathrm{B}| \neq 0$ artinya model persamaan nilai tukar rupiah (2) merupakan persamaan yang teridentifikasi sehingga pendekataan Two Stage Least Square dapat digunakan.

Hasil identifikasi masalah dengan menggunkan uji kondisi order dan kondisi rank diperoleh kesimpulan bahwa model persamaan inflasi (1) dan nilai tukar rupiah (2) dapat teridentifikasi, yang artinya kedua model persamaan tersebut dapat dilanjutkan ketahapan estimasi parameter dengan menggunkan pedekatan Two Stage Least Square.

\subsection{Estimasi Parameter}

Estimasi parameter yang digunakan pada penelitian ini menggunakan pendekatan two stage least square, karena pada persamaan simultan terdapat suatu variabel yang saling mempengaruhi, 
dimana variabel endogen akan menjadi variabel eksogen pada persamaan lain. Sehingga untuk penggunaan 2SLS ini dapat dilihat berdasarkan hasil yang didapatkan pada tahapan identifikasi masalah dengan uji kondisi order dan kon- disi rank, apabila hasil yang diperoleh meyatakan kedua model persamaan simultan saling teridentifikasi maka dapat digunakan pendekatan 2SLS, akan tetapi jika hasil yang diperoleh pada model persamaan simultan tidak teridentifikasi maka pendekatan 2SLS tidak dapat digunakan tetapi pendekatan yang bisa digunakan adalah OLS.

\subsubsection{Estimasi Parameter Model Persamaan Inflasi (INF)}

Berdasarkan hasil estimasi menggunakan pendeketan Two Stage Least Square untuk pesamaan inflasi (1) menghasilkan nilai $R^{2}$ sebesar $57,66 \%$, yang artinya keragaman nilai inflasi telah mampu dijelskan oleh variabel prediktor sebesar 57,66\% Hasil estimasi parameter dengan pendekatan Two Stage Least Square untuk model persamaan inflasi (1) disajikan pada Tabel 5.

Tabel 5. Nilai estimasi paramter pada model persamaan inflasi

\begin{tabular}{cccc}
\hline Variabel & Koefisien & t-statistik & $p$-value \\
\hline $\mathrm{C}$ & $-7,553017$ & $-1,469808$ & 0,1589 \\
$\mathrm{ER}$ & 0,001614 & 2,195028 & 0,0415 \\
$M_{2}$ & $-0,0000223$ & $-2,103563$ & 0,0497 \\
$\mathrm{R}$ & 0,340971 & 1,107823 & 0,2825 \\
\hline
\end{tabular}

Berdasarkan Tabel 5 diketahui bahwa variabel yang berpengaruh signifikan terhadap inflasi (INF) adalah varaiabel nilai tukar rupiah (ER) dan jumlah uang (M2) beredar. Model persamaan untuk inflasi sebagai berikut.

$$
\widehat{Y}=-7,553017+0,001614 Y_{2}-0,0000223 X_{1}+0,34097 X_{2}
$$

Dari model persamaan untuk inflasi (3) menunjukan bahwa variabel nilai tukar rupiah (ER) berpengaruh positif terhadap inflasi yang artinya bahwa setiap peningkatan 1 dolar akan meningkatkan inflasi sebesar $0,0016 \%$. Demikian juga jumlah uang beredar $\left(M_{2}\right)$ variabel ini berpengaruh negatif terhadap inflasi, yang artinya setiap ada penam- bahan jumlah uang beredar $\left(M_{2}\right)$ akan menurunkan inflasi sebesar 0,0000223\%. Sedangkan variabel tingkat suku bunga (R) berpengaruh positif terhadap inflasi akan tetapi pengaruhnya tidak signifikan terhadap inflasi yang dapat dilihat dengan nilai $p$-value lebih besar dari 0,05 .

\subsubsection{Estimasi Parameter Model Nilai Tukar Rupiah (ER)}

Berdasarkan hasil estimasi menggunakan pendeketan Two Stage Least Square untuk pesamaan nilai tikar rupiah (2) menghasilkan nilai $R^{2}$ sebesar $88,57 \%$, yang artinya keragaman nilai tukar rupiah telah mampu dijelskan oleh variabel prediktor sebesar 88,57\%. Hasil estimasi parameter dengan pendekatan Two Stage Least Square untuk model persamaan nilai tikar rupiah (2) disajikan pada Tabel 6.

Tabel 6. Nilai estimasi paramter pada model persamaan nilai tukar rupiah

\begin{tabular}{cccc}
\hline Variabel & Koefisien & t-statistik & $p$-value \\
\hline C & 6722,594 & 8893,910 & 0,0000 \\
INF & 190,5307 & 3,352546 & 0,0035 \\
$M_{2}$ & 0,001210 & 11,19867 & 0,0000 \\
PDB & $-126,4699$ & $-0,949418$ & 0,3550 \\
\hline
\end{tabular}

Berdasarkan Tabel 6 diketahui bahwa variabel yang berpengaruh signifikan ter- hadap nilai tukar rupiah (ER) adalah varaiabel infLasi (INF) dan jumlah uang $\left(M_{2}\right)$ beredar. Model persamaan 
untuk nilai tukar rupiah sebagai berikut.

$$
\widehat{Y}=6722,594+190,5307 Y_{1}+0,001210 X_{1}-126,4699 X_{3}
$$

Berdasarkan model persamaan (4) menunjukan bahwa variabel inflasi (INF) berpengaruh positif terhadap nilai tukar rupiah (ER) yang artinya bahwa setiap peningkatan $1 \%$ pada inflasi maka akan meningkatkan nilai tukar rupiah sebesar Rp.190,531. Demikian juga jumlah uang beredar $\left(\mathbf{M}_{2}\right)$ variabel ini berpengaruh positif terhadap nilai tukar rupiah, yang artinya setiap ada penambahan jumlah uang beredar $\left(\mathrm{M}_{2}\right)$ akan meningkatkan nilai tukar rupiah sebesar Rp 0,001210. Sedangkan variabel pertumbuhan ekonomi (PDB) berpengaruh negatif dan tidak signifikan terhadap nilai tikar rupiah, yang dapat dilihat dengan nilai $p$-value lebih besar dari 0,05.

\subsection{Pengujian Asumsi Klasik}

Pengujian asumsi klasik dibutuhkan sebagai dasar untuk memastikan bahwa model persamaan 3 dan 4 termasuk kedalam estimasi yang baik atau tidak. Pada model persamaan simultan pengujian asumsi klasik yang hasur dilakukan adalah asumsi normalitas, heteroskedastisitas, autokorelasi dan multikolinearitas.

\subsubsection{Asumsi Normalitas}

Asumsi normalitas digunakan dalam mengetahui apakah nilai dari residual pada persamaan regresi berdistribusi normal atau tidak berdistribusi normal. Untuk mengidentifikasi normalitas, dibutuhkan uji Jarque-Bera dengan hipotesis sebagai berikut:

$H_{0}$ : Data berdistribusi normal

$H_{1}$ : Data tidak berdistribusi normal

Hasil pengujian asumsi normalitas disajikan pada Tabel 7.

Tabel 7. Hasil Asumsi Normalitas

\begin{tabular}{ccc}
\hline Persamaan & $P$-Value & Keterangan \\
\hline INF & 0,203529 & Gagal tolak $H_{0}$ \\
ER & 0,6537457 & Gagal tolak $H_{0}$ \\
\hline
\end{tabular}

Berdasarkan Tabel 4.7 dapat diketahui nilai p-value menggunakan uji Jarque-Bera pada persamaan inflasi (INF) sebesar 0,203529 dan nilai tukar rupiah (ER) sebesar 0,6537457, yang artinya lebih besar dari 0,05 , sehingga gagal tolak $H_{0}$. Dengan demikian dapat disimpulkan bahwa model persamaan 3 dan 4 memenuhi asumsi residual berdistribusi normal.

\subsubsection{Asumsi Heteroskedastisitas}

Asumsi hetorskedastisitas digunakan untuk mengetahui apakah terdapat model yang memiliki varians yang sama dari residual satu pengamatan kepengamatan yang lain. Uji yang digunakan untuk melakukan asumsi heteroskedastisitas adalah uji Glejser dengan hipotesis:

$H_{0} \quad: \beta_{k}=0$ (Tidak terjadi heteroskedastisitas)

$H_{1} \quad: \beta_{k}=0 ; k=1,2, \ldots, K$ (Terjadi heteroskedastisitas)

Hasil pengujian asumsi heteroskedastisitas disajikan pada Tabel 8.

Tabel 8. Hasil Asumsi Heteroskedastisitas

\begin{tabular}{ccc}
\hline Persamaan & $P$-Value & Keterangan \\
\hline INF & 0,6358 & Gagal tolak $H_{0}$ \\
ER & 0,9323 & Gagal tolak $H_{0}$ \\
\hline
\end{tabular}


Berdasarkan Tabel 8 dapat diketahui nilai $p$-value menggunakan uji Glejser pada persamaan inflasi (INF) sebesar 0,6358 dan nilai tukar rupiah (ER) sebesar 0,9323, yang artinya lebih besar dari 0,05 , sehingga gagal tolak $H_{0}$. Dengan demikian dapat disimpulkan bahwa model persamaan 3 dan 4 memenuhi asumsi heteroskedastisitas.

\subsubsection{Asumsi Autokorelasi}

Asumsi autokorelasi digunakan untuk mengetahui apakah terdapat model yang memiliki varians yang sama dari residual satu pengamatan kepengamatan yang lain. Uji yang digunakan untuk melakukan asumsi autokorelasi adalah uji Lagrange Multiplier Test (LM Test) dengan hipotesis:

$H_{0} \quad$ : Tidak terjadi autokorelasi

$H_{1} \quad$ : Terjadi autokorelasi

Hasil pengujian asumsi autokorelasi disajikan pada Tabel 9.

Tabel 9. Hasil Asumsi Autokorelasi

\begin{tabular}{ccc}
\hline Persamaan & $P$-Value & Keterangan \\
\hline INF & 0,9787 & Gagal tolak $H_{0}$ \\
ER & 0,4747 & Gagal tolak $H_{0}$ \\
\hline
\end{tabular}

Berdasarkan Tabel 4.9 dapat diketahui nilai p-value menggunakan uji Lagrange Multiplier Test (LM Test) pada persamaan inflasi (INF) sebesar 0,9787 dan nilai tukar rupiah (ER) sebesar 0,4747 , yang artinya nilai tersebut lebih besar dari 0,05 , sehingga gagal tolak $H_{0}$. Dengan demikian dapat disimpulkan bahwa model persamaan 3 dan 4 memenuhi asumsi autokorelasi.

\subsubsection{Asumsi Multikolinearitas}

Uji multikolinieritas digunakan dalam melihat apakah terjadi korelasi yang kuat antar variabel prediktor, mengidentifikasi apakah terindikasi adanya multikolinieritas dalam model dapat dilihat dengan cara menganalisis matriks korelasi yang cukup tinggi (umumnya diatas 0,90), maka hal ini mengindikasikan adanya multikolinearitas. Hasil pengujian asumsi multikolinearitas untuk inflasi dan nilai tukar rupiah masing-masing disajikan pada Tabel 10 dan Tabel 11.

Tabel 10. Hasil Asumsi Multikolinearitas untuk Inflasi

\begin{tabular}{cccc}
\hline & $\mathrm{ER}$ & $\boldsymbol{M}_{2}$ & $\mathrm{R}$ \\
\hline $\mathrm{ER}$ & 1 & 0,90 & $-0,54$ \\
$M_{2}$ & 0,90 & 1 & $-0,76$ \\
$\mathrm{R}$ & $-0,54$ & $-0,76$ & 1 \\
\hline
\end{tabular}

Tabel 11. Hasil Asumsi Multikolinearitas untuk Nilai Tukar Rupiah

\begin{tabular}{cccc}
\hline & INF & $M_{2}$ & PDB \\
\hline INF & 1 & $-0,55$ & 0,25 \\
$M_{2}$ & $-0,55$ & 1 & 0,03 \\
R & $-0,25$ & 0,03 & 1 \\
\hline
\end{tabular}

Berdasarkan Tabel 10 dan 11 dmenunjukan bahwa matriks yang dihasilkan tidak terdapat nilai yang lebih besar dari 0,9 sehingga dapat disimpulkan bahwa tidak terjadi multikolonieritas dalam regresi tersebut. Dengan demikian dapat disimpulkan bahwa model persamaan 3 dan 4 memenuhi asumsi multikolinearitas.

Berdasarkan uji asumsi klasik yang telah dilakukan, dapat disimpulkan bahwa model persamaan untuk inflasi (3) dan nilai tukar rupiah (4) pada model persamaan simultan yang telah 
diuji menggunakan pendekatan two stage least square telah meng- hasilkan model estimasi yang baik.

\subsection{Memprediksi Nilai dengan Menggunakan Model Persamaan Inflasi dan Nilai Tukar Rupiah}

Dalam menentukan hasil prediksi dapat dilakukan pengukuran tingkat kesalahan- nya, dengan cara setiap model yang akan dilakukan prediksinya divalidasi menggu- nakan sejumlah indikator. Salah satu indikator yang digunakan adalah rata-rata pre- sentase kesalahan absolut (Mean Absolute Precentage Error). Dalam menetukan rentang nilai yang menunjukkan arti nilai persentase error pada MAPE, dimana nilai MAPE masih bisa digunakan apabila tidak melebihi $50 \%$, jika nilai MAPE sudah di atas 50\% maka model prediksi tersebut tidak bisa digunakan. Artinya Semakin kecil nilai presentasi kesalahan (percentage error) pada MAPE maka semakin akurat hasil prediksi tersebut.

\subsubsection{Nilai Prediksi dengan Menggunakan Model Persamaan Inflasi}

Model persamaan simultan dengan pendekatan two stage least square untuk inflasi direpresentasikan pada persamaan berikut:

$$
\widehat{Y}=-7,553017+0,001614 Y_{2}-0,0000223 X_{1}+0,34097 X_{2}
$$

Berdasakan model persamaan inflasi nilai koefisien dari masing-masing variabel sudah di ketahui maka, nilai prediksi inflasi dapat di hitung dengan mensubstitusikan nilai dari variabel bebas kedalam model. Hasil prediksi untuk model persamaan inflasi disajikan dalam Tabel 12.

Tabel 12. Data Aktual dan Hasil Prediksi Model Inflasi Tahun 2010-2020

\begin{tabular}{rccc}
\hline \multirow{2}{*}{ Tahun } & \multicolumn{3}{c}{ Mode lnflasi } \\
\cline { 2 - 3 } & Data Aktual $\left(A_{t}\right)$ & Data Hasil Prediksi $\left(F_{t}\right)$ & $A_{t}-F_{t}$ \\
\hline 2010 & 6,96 & 3,66 & 3,30 \\
2011 & 3,79 & 2,91 & 0,88 \\
2012 & 4,30 & 2,65 & 1,65 \\
2013 & 8,38 & 6,01 & 2,37 \\
2014 & 8,36 & 5,78 & 2,58 \\
2015 & 3,35 & 6,61 & $-3,26$ \\
2016 & 3,02 & 5,02 & $-2,00$ \\
2017 & 3,61 & 3,78 & $-0,17$ \\
2018 & 3,13 & 4,71 & $-1,58$ \\
2019 & 2,72 & 3,12 & $-0,40$ \\
2020 & 1,68 & 1,27 & 0,41 \\
\hline \multicolumn{2}{c}{ Nilai MAPE } \\
\hline
\end{tabular}

Berdasarkan hasil prediksi model persamaan inflasi menghasilkan nilai MAPE untuk model persamaan inflasi sebesar $0,08 \%$. Artinya nilai MAPE yang diperoleh tidak melebihi $50 \%$. Dengan demikian dapat disimpulkan bahwa hasil prediksi model inflasi menunjukan hasil prediksi yang akurat. 


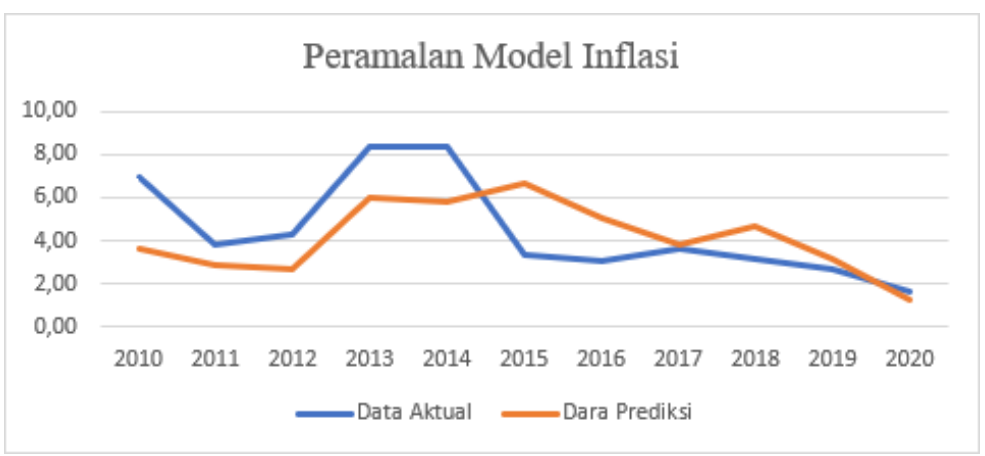

Gambar 6. Peramalan Model Inflasi

Berdasarkan Gambar 6 dapat dilihat bahwa data prediksi menghampiri data aktual sehingga dapat disimpulkan nilai prediksi dengan menggunakan model persamaan inflasi dapat dikatakan baik.

\subsubsection{Nilai Prediksi dengan Menggunakan Model Persamaan Nilai Tukar Rupiah}

Model persamaan simultan dengan pendekatan two stage least square untuk nilai tukar rupiah direpresentasikan pada persamaan berikut:

$$
\widehat{Y}=6722,594+190,5307 Y_{1}+0,001210 X_{1}-126,4699 X_{3}
$$

Berdasakan model persamaan inflasi nilai koefisien dari masing-masing variabel sudah di ketahui maka, nilai prediksi inflasi dapat di hitung dengan mensubsti tusikan nilai dari variabel bebas ke dalam model. Hasil prediksi untuk model persamaan niali tukar rupiah disajikan dalam Tabel 13.

Tabel 13. Data Aktual dan Hasil Prediksi Model Nilai Tukar Rupiah Tahun 2010-2020

\begin{tabular}{cccc}
\hline \multirow{2}{*}{ Tahun } & \multicolumn{2}{c}{ Model Inflasi } & \multirow{2}{*}{$A_{t}-F_{t}$} \\
\cline { 2 - 3 } & Data Aktual $\left(A_{t}\right)$ & Data Hasil Prediksi $\left(F_{t}\right)$ & \\
\hline 2010 & 8991 & 10267 & -1276 \\
2011 & 9068 & 10104 & -1036 \\
2012 & 9670 & 10756 & -1086 \\
2013 & 12440 & 12730 & -290 \\
2015 & 13795 & 12354 & 1441 \\
2016 & 13436 & 12719 & 717 \\
2017 & 13548 & 13311 & 237 \\
2018 & 14481 & 13635 & 846 \\
2019 & 13901 & 14027 & -126 \\
2020 & 14105 & 15130 & -1025 \\
\hline \multicolumn{3}{c}{} \\
\hline
\end{tabular}

Berdasarkan hasil prediksi model persamaan nilai tukar rupiah yang diperoleh pada Tabel 13 menghasilkan nilai MAPE untuk model persamaan nilai tukar rupiah sebesar 0,101\%. sehinga nilai MAPE yang diperoleh tidak melebihi 50\%. Dengan demikian dapat disimpulkan bahwa hasil prediksi model nilai tukar rupiah menunjukan hasil prediksi yang akurat. 


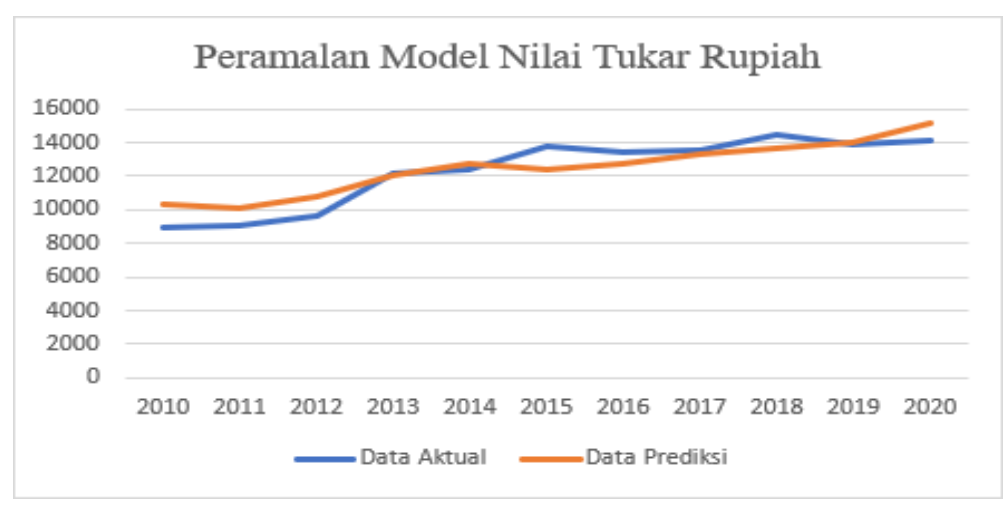

Gambar 7. Peramalan Model Nilai Tukar Rupiah

Berdasarkan Gambar 7 dapat dilihat bahwa data prediksi menghampiri data aktual sehingga dapat disimpulkan nilai prediksi dengan menggunakan model persamaan inflasi dapat dikatakan baik.

\section{Kesimpulan}

Model persamaan simultan dengan pendekatan two stage least square untuk inflasi dapat dilihat pada persamaan 3. Berdasarkan persamaan inflasi tersebut dapat dikatakan bahwa faktor yang mempengaruhi inflasi adalah nilai tukar rupiah $\left(Y_{2}\right)$ dan jumlah uang beredar $\left(X_{1}\right)$, sedangkan tingkat suku bunga $\left(X_{2}\right)$ tidak berpengaruh terhadap inflasi. Sementara itu, model persamaan simultan dengan pendekatan two stage least square untuk nilai tukar rupiah dapat dilihat pada persamaan 4. Berdasarkan persamaan nilai tukar rupiah tersebut dapat dikatakan bahwa faktor yang mempengaruhi nilai tukar rupiah adalah inflasi $\left(Y_{1}\right)$ dan jumlah uang beredar $\left(X_{1}\right)$, sedangkan pertumbuhan ekonomi $\left(X_{3}\right)$ tidak berpengaruh terhadap nilai tukar rupiah. Hasil prediksi dari persamaan inflasi dan nilai tukar rupiah dengan menggunakan indikator MAPE memperoleh nilai MAPE lebih kecil dari 0,5\%. Dengan demikian dapat disimpulkan bahwa hasil prediksi persamaan inflasi dan nilai tukar rupiah menunjukan hasil prediksi yang akurat.

\section{Referensi}

[1] D. Gujarati, Ekonometrika dasar, Jakarta: Erlangga, 1978.

[2] A. Koutsoyiannis, Theory of econometrics an introductory exposition of econometric methods, Macmillan: Basingstoke, 1977.

[3] T. R. Daniantari, "Estimasi Model Persamaan Simultan Dengan Metode Two Stage Least Square dan Penerapannya," Eprints Universitas Negeri Yogyakarta, 2011.

[4] M. Ekananda, Ekonometrika Dasar, Jakarta: Mitra Wacana Media, 2015.

[5] D. Gujarati, Ekonometria Dasar, Terjemahan: Drs. Ak. Sumarno Zain, Jakarta: Erlangga, 2003.

[6] R. L. Basmann, "A generalized classical method of linear estimation of coefficients in a structural equation," Journal of the Econometric Society, pp. 77-83, 1957.

[7] T. A, Ventus, Econometrics, Publishing ApS, 2007.

[8] S. Sukirno, Makroekonomi Modern, Jakarta: PT RajaGrafindo Persada, 2000.

[9] M. N. Gregory, Principles of Economics Pengantar Ekonomi Makro, Jakarta: Salemba Empat, 2006.

[10] N. A. Fery, "Analisa Faktor-Faktor yang Mempengaruhi Inflasi di Indonesia Periode 1997," Economic Journal of Emerging Markets, vol. 11 no 2, pp. 173-186, 2006.

[11] H. Theil, Repeated least squares applied to complete equation systems, The Hague: Central Planning Bureau, 1953. 
[12] F. A. M. Ardiyanto, "Pergerakan Nilai Tukar Rupiah Terhadap Dolar Amerika Dalam Dua Periode Penerapan Sistem Nilai Tukar," urnal Ekonomi \& Studi Pembangunan, vol. 15 no. 2, pp. 27-134, 2014.

[13] S. Kuznets, "Penerapan Metode Two Stage Least Squares Pada Model Persamaan Simultan Dalam Memprediksi PDRB dan Pertumbuhan Ekonomi," 2016.

[14] E. S. Misno, "Estimasi Model Persamaan Simultan Dengan Metode Two Stage Least Square (2SLS)," BIMASTER, vol. 8 no. 4, 2019.

[15] R. F. Rahmadeni, "Model Persamaan Simultan Pada Analisis Hubungan Nilai Tukar Rupiah dan Inflasi," Jurnal Sains Matematika dan Statistika, vol. 6 no. 2, pp. 73-79, 2020. 